\title{
THE VARIANCE AND TREND OF INTEREST RATE - CASE OF COMMERCIAL BANKS IN KOSOVO
}

Fidane Spahija ${ }^{1}$

\begin{abstract}
Today's debate on the interest rate is characterized by three key issues: the interest rate as a phenomenon, the interest rate as a product of factors (dependent variable), and the interest rate as a policy instrument (independent variable). In this article, the variance in interest rates, as the dependent variable, comes in two statistical sizes: the variance and trend. The interest rates include the price of loans and deposits. The analysis of interest rates on deposits and loan is conducted for non-financial corporation and family economy. This study looks into a statistical analysis, to highlight the variance and trends of interest rates for the period 2004-2013, for deposits and loans in commercial banks in Kosovo. The interest rate is observed at various levels. Is it high, medium or low? Does it explain growth trends, keep constant, or reduce? The trend is observed whether commercial banks maintain, reduce, or increase the interest rate in response to the policy that follows the Central Bank of Kosovo. The data obtained will help to determine the impact of interest rate in the service sector, investment, consumption, and unemployment.
\end{abstract}

JEL Classification Numbers: G21, G210, G290, DOI: http://dx.doi.org/10.12955/cbup.v3.577

UDC Classification: 657

Keywords: Interest rate, deposits, loans, impact, trends, variances

\section{Introduction}

Commercial banks are the main source of sustainable economic development of a country. The main activity of commercial banks is taking deposits and giving loans. These activities are undertaken at a price, and that price is recognized as an interest rate. By many different authors and theory, the interest rate is seen as a product of factors (dependent variable) and as a policy instrument (independent variable). The main purpose of this article is to investigate variances and trends of interest rates on loans and deposits in commercial banks in Kosovo during the last decade. Only by analyzing variances and interest rate trends can we arrive at some conclusion as to where and how they affect the interest rate. In cases where interest rates decline, borrowing becomes more attractive leading to increased demand for goods, investment, and consumption. Consequently, investment growth contributes the most to economic development.

\section{Data and methodology}

The research was conducted according to the methods of statistical analysis using an average size of algebraic and absolute indicators of variation. To achieve the objectives of the research, the research is based on primary and secondary data. The primary data for this study were obtained from published reports of the Central Bank of Kosovo and other literature. While secondary data are provided through similar research published and basic text books. Data are obtained for ten years and through comparative and analytical method over the years in which results are defined. This article is divided into four main parts. The second part of the article contains a review of the literature. The third part of the article contains the presentation of data to the interest rate on loans and deposits for the last ten years. The fourth part of the article shows the trend of how interest rates vary from year to year. The recommendations are present in the last part of the article.

\section{Literature review}

Many debates on interest rate exists today. There are many different authors and theories which speak about interest rates. The main theories of interest rates (Rothbard, 2001) are:

\footnotetext{
${ }^{1}$ Fidane Spahija, lecturer in Faculty of Business in finance and accounting courses, University "Haxhi Zeka," Peja, Kosovo, fidane.spahija@unhz.eu
} 
- Theory of Austrian School, with the main representatives: Eugen von Bohm Bawerk (18411914); Ludwig von Mises (1881-1973). According to this theory, the interest rate charges explained how the law of marginal utility of goods (Friedrich von Wieser, 1851-1926) that has to do with "time-preference" of people to capital, money, goods exchanged/produced (Eugen von Bohm Bawerk, Capital and Interests, 1890); exchange practices/choice of goods (the current vs future), and through transactions that perform (commodity, money, loan) (Ansgar Belke, 2009).

- Neo-Classical Theory, with the main representatives: Jeremy Bentham (1748-1832); Carl Menger (1840-1921); Leon Walras (1834-1919); Hermann Heinrich Gossen (1810-1858). According to this theory, the interest rate is explained by the laws of decreasing marginal utility (Hermann Heinrich Gossen 1810-1858) whom: Law 1: increased consumption of a commodity generates a positive benefit, but the satisfaction of additional consumption may not be so great as that generated by the previous consumption; Law 2: in an optimal condition, the ratio of exchange of goods/price is equal to the ratio of marginal utility of goods in circulation (Ansgar Belke, 2009).

- Theory of liquidity with the main representatives: John Maynard Keynes (1883-1946). According to this theory, interest rates are explained by the role of money (demand-supply) (Ansgar Belke, 2009).

- Theory of loan with the main representatives: Knut Wicksell (1851-1926). The Interest Rate explains the difference/neutral norm deviance (the economy) vs free rate (the market) (Ansgar Belke, 2009).

A great contribution is made by the laureate Nobel, F. Modigliani and the other followers of Keynes's (Aristotel Pano, 2007). The higher interest rates increase the cost of credit and discourage borrowing. On the opposite side, the bigger the debt (low solvency) the higher will the interest rate (Mayo, 2012). Interest rate fluctuations affect lending, investment, production, employment, consumption, and savings, directly influencing the real economy (Bujar Leskaj, 2011). From the different theories of interest mentioned above, it is clear that most authors consider interest as the price of money. The discussion of authors today focus on finding concrete solutions to the monetary policy and interest rate levels for the rapid development of balanced macroeconomics and to reduce inflation and unemployment. Foreign banks have higher margins and profits compared to domestic banks in developing countries, while the opposite holds true in developed countries (Asli DemirgüçKunt, 1998). High margins bring stability to the banking system, so they increase profitability and capital of the bank in order to isolate banks from various externalities and social costs. Therefore, many countries, in the absence of functioning capital markets, generate profit margins because it is the only means that the bank can augment its capital base (Anthony Saunders, 2000).

\section{Banks and interest rates in Kosovo}

The reform of the banking system in Kosovo, after the war began in 1999, led by the Banking and Payments Authority of Kosovo (BPK) as the forerunner of the Central Bank of Kosovo (CBK). The banking system plays a very important role in the financial system in Kosovo, whose assets constitute about 90 percent of the assets of the entire financial system. The structure of the banking sector in Kosovo in 2014 is similar to the previous periods. According to the ownership, structure of the banking sector continued to be dominated by foreign-owned banks, whose assets constitute 89.9 percent of total banking sector assets, while the remainder is managed by domestically-owned banks. The following table shows that the number of commercial banks operating in Kosovo is nine, with a total of 298 subsidiaries. 


\begin{tabular}{|c|c|c|}
\hline \multicolumn{3}{|c|}{ Table 1: Commercial banks and their existing branches in Kosovo } \\
\hline $\mathbf{N o .}$ & \multicolumn{1}{|c|}{ Name bank } & Existing branches \\
\hline $\mathbf{1 .}$ & Procredit Bank & 55 \\
\hline $\mathbf{2 .}$ & Raiffeisen Bank Kosovo J.S.C & 50 \\
\hline $\mathbf{3 .}$ & NLB Prishtina & 41 \\
\hline $\mathbf{4 .}$ & Business Bank & 40 \\
\hline $\mathbf{5 .}$ & Economy Bank & 26 \\
\hline $\mathbf{6 .}$ & TEB & 24 \\
\hline $\mathbf{7 .}$ & National Commercial Bank & 9 \\
\hline $\mathbf{8 .}$ & Komercijalna Banka - Mitrovica & $\mathbf{2 9 8}$ \\
\hline $\mathbf{9 .}$ & Turkiye is bankasi - Pristina & Total \\
\hline & 2 & \\
\hline
\end{tabular}

Source: Central Bank of Kosovo (2014)

\section{The effective interest rate of deposits and loans}

Table 2 shows the average interest rates on deposits. The analysis is conducted for two main categories of deposits in commercial banks in Kosovo, which are non-financial corporate deposits and deposits of households. Deposits of non-financial corporation may be transferable deposits, other deposits, and savings deposits. Other deposits may be less than and more than 250,000€, which can be deposited for a month, one to three months, and from six to 12 months. The classification is also identical for household deposits, in which other deposits, however, can also be deposited within 12 to 24 months and over 20 months. The highest average interest rate of deposits in commercial banks in Kosovo was 4.3 percent in 2009, and the lowest was 2.8 percent in 2004.

Table 3 shows the average interest rates on loans. Also, the two main categories of loans in commercial banks in Kosovo are: non-financial corporate loans and household loans. Loans of nonfinancial corporation's may be investing loan, non-investing loan, overdraft, credit lines, and cover loans with deposits. Investing loan has maturity of the following periods: one year, one to five years and over five years. While non-investing loan has only two maturity periods: one year and one to five years. The classifications of household loans are: overdraft, cover loans with deposits, consumer loans, and mortgage loans. Maturity of mortgage loans is one to five years and over five years. The highest average interest rate of loans in commercial banks in Kosovo was 15.0 percent in 2004, and the lowest was 12.4 percent in 2013.

Table 2 and Table 3 are shown in the Appendix.

\section{The variance and tendencies of interest rate in commercial banks in Kosovo}

The importance of interest rates in a country's economy has been mentioned by many of authors. The following figures show the correlation between the interest rates of deposits and loans in commercial banks in Kosovo over the past ten years. In Figure 1, it can be seen that the highest average interest rate of deposits in commercial banks in Kosovo was 4.3 percent in 2009, and the lowest was 2.8 percent in 2004. On the contrary, it can be seen that the highest average interest rate of loans in commercial banks in Kosovo was 15.0 percent in 2004, and the lowest was 12.4 percent in 2013. 


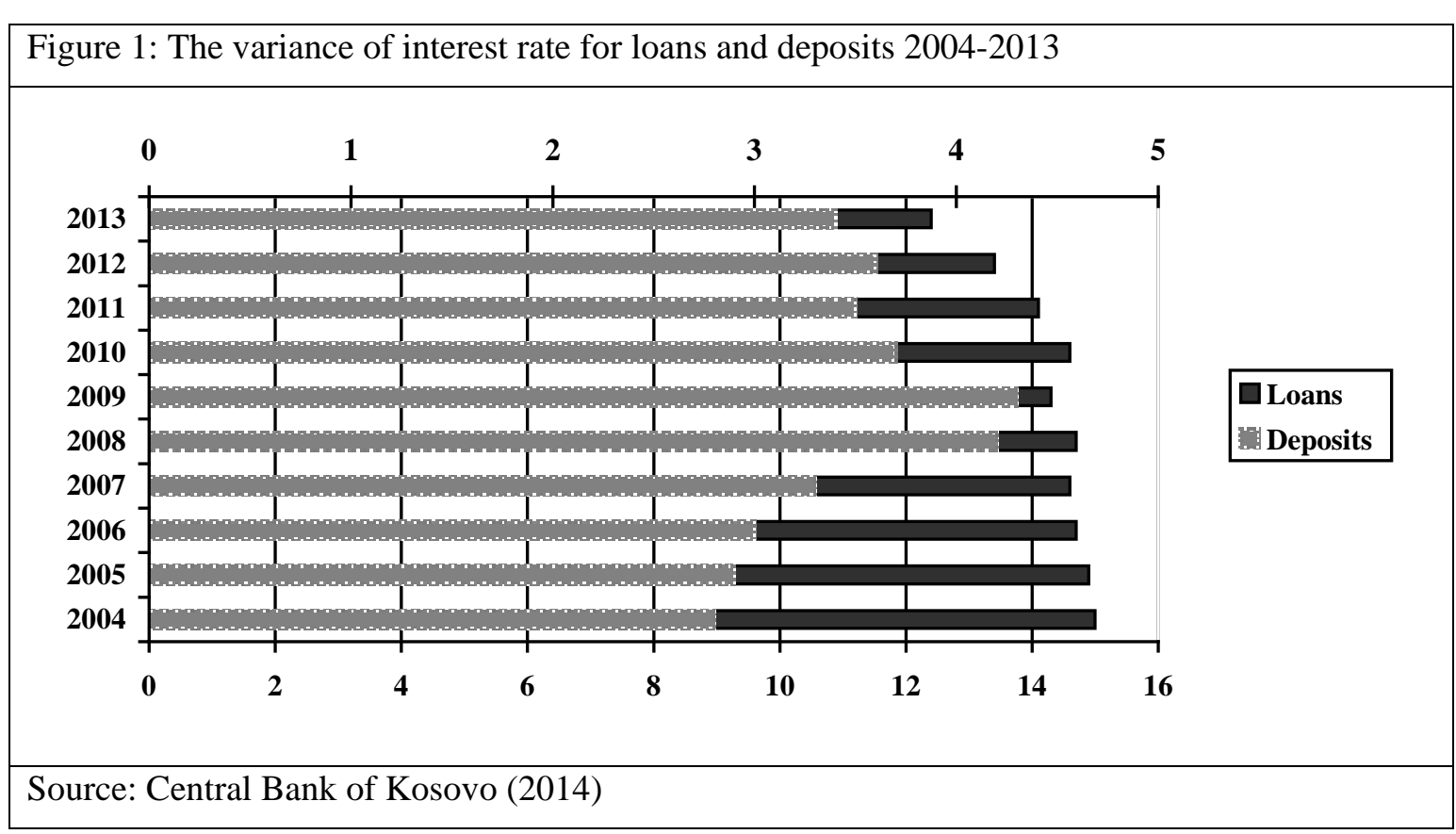

Figure 2: The tendencies of interest rate for loans and deposits (2004-2013)

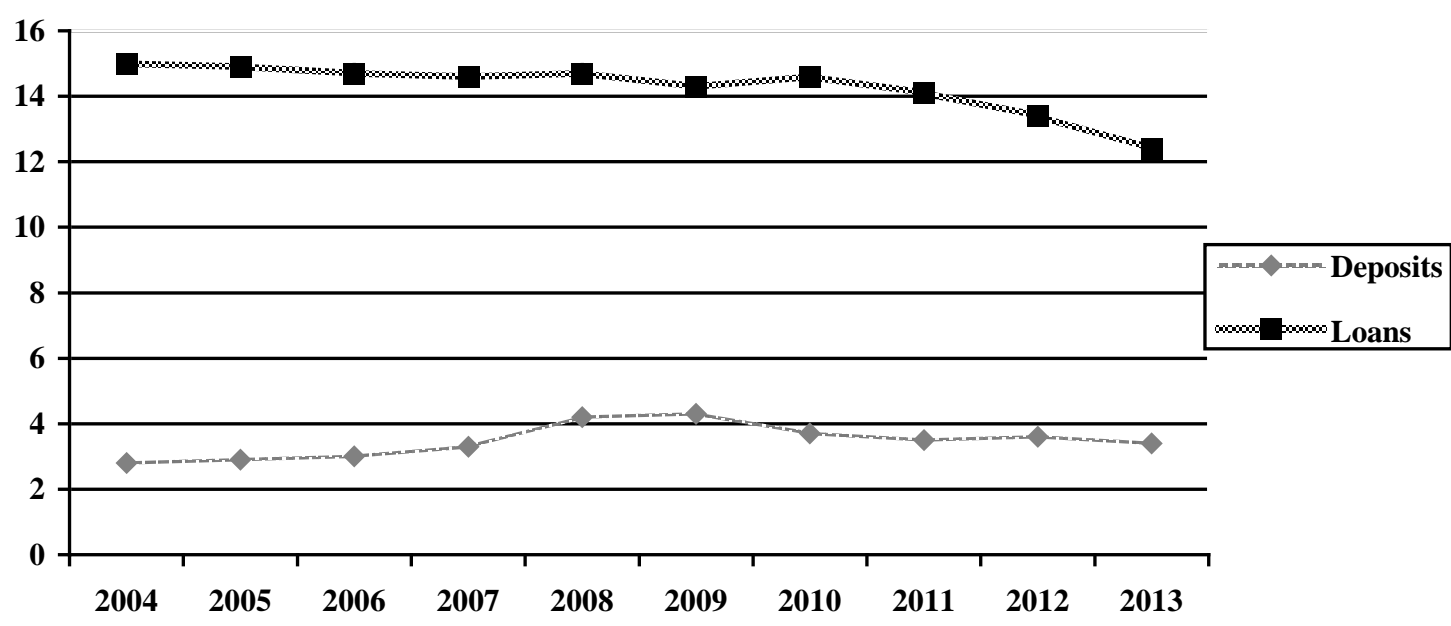

Source: Central Bank of Kosovo (2014)

By comparison and analysis of these data in Figure 2, the trend movement from year to year can be observed. The trend of the deposit indicates that it is recording a fall, which testifies the results of 2014, where the interest rate is 2.0; meanwhile, the trend of loans continuously declined, but 2014 remained constant with the previous year.

\section{Results and discussion}

From the results obtained, we can say that the deposit interest rates have declined greater than the interest rates on loans. The condition of the interest rates on loans and deposits in Kosovo is not satisfactory. While the trend of deposits has declined in recent years, it shows that banks have sufficient liquidity and do not need to collect deposits. It is expected that the deposit interest rate will reduce to attract depositors from banks and invested savings or increase consumption. While the trend of loans is a slight decline, the interest rate remains in double digits compared with other 
developing countries. According to businesses and individuals, these rates are still high and are suffocating the country's economy. According to commercial banks, credit interest rates will remain the same until the court accelerates the procedures of obtaining a collateral pledge, while many banks tend not to consider the high risk of repayment from potential borrowers.

\section{Conclusion}

From this article, the conclusion may be drawn that interest rates are playing an important role in the economic development of a country. The frequent crises have led to the debate of an increase in interest rates all over the world. Therefore, special attention must be given to the fluctuation in interest rates. During the past decade, deposit interest rates have declined more than those of the loans; this indicates that banks have sufficient liquidity. However the regulation and accelerated court procedures, for obtaining a collateral pledge, and the identification of factor in reducing the rate of interest on loans may have an impact on a more sustainable economic development.

\section{References}

Ansgar Belke, T. P. (2009). Monetary economics in globalised financial markets. Berlin: Springer.

Anthony Saunders, L. S. (2000). The determinants of bank interest rate margins: an international study. Journal of International Money and Finance, 813-832.

Aristotel Pano, E. G. (2007). Financial Markets. Tiranë: Albin.

Asli Demirgüç-Kunt, H. H. (1998). Determinants of commercial bank interest margins and profitability. World Bank, 1. Bujar Leskaj, A. K. (2011). Money and Banking. Tiranë: GEER.

Mayo, H. B. (2012). Basic of Finance. Tiranë: UET.

Rothbard, M. N. (2001). Man, Economy and State. Alabama: Ludwig Von Mises Institute.

Central Bank of Kosovo (2014). Annual report. Retrieved from http://bqk-kos.org.s140684. gridserver.com/index.php?id=102\&ar=1 


\section{Appendix}

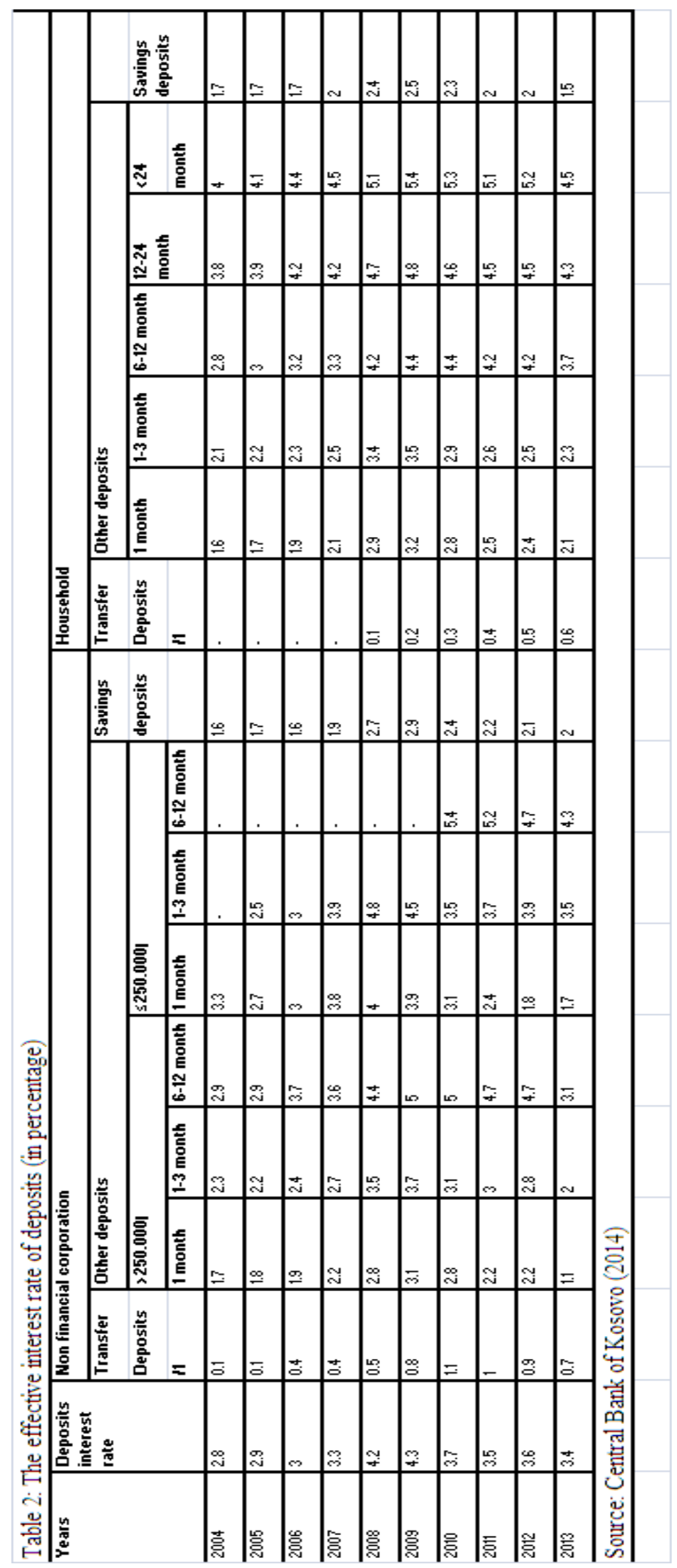




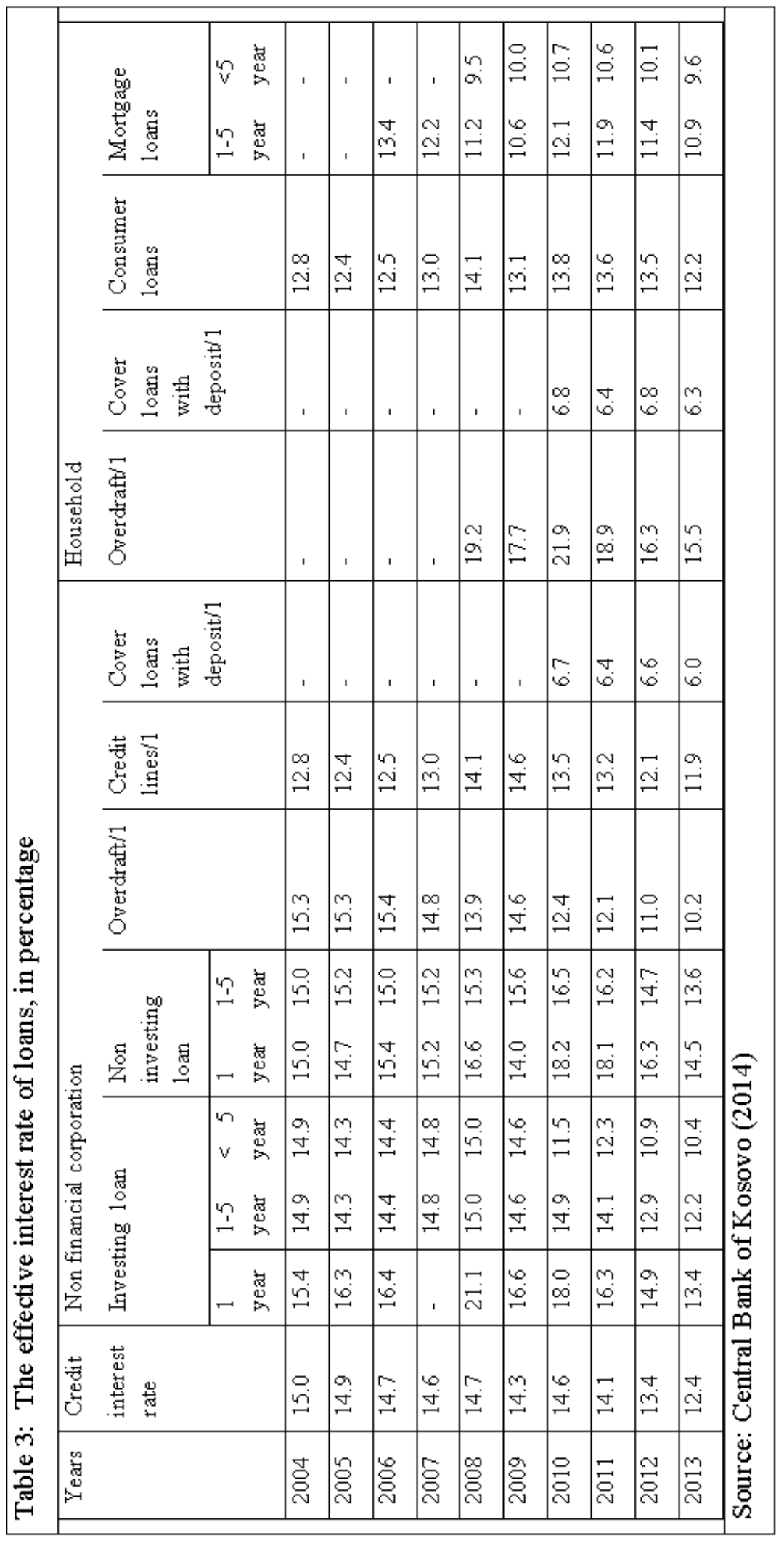

